Revista Brasileira de Agricultura Irrigada v.11, nº.5, p. 1714 - 1722, 2017

ISSN 1982-7679 (On-line)

Fortaleza, CE, INOVAGRI - http://www.inovagri.org.br

DOI: $10.7127 /$ rbai.v11n500764

Protocolo 764.17 - 23/05/2017 Aprovado em 31/08/2017

\title{
ESTIMATE OF THE REFERENCE EVAPOTRANSPIRATION OF THE POÇO VERDE REGION
}

\author{
Raimundo Rodrigues Gomes Filho ${ }^{1}$, Igor Leonardo Nascimento Santos ${ }^{2}$, Leno Gonzaga de \\ Souza $^{3}$, Ketylen Vieira Santos ${ }^{4}$, Débora Thalita Brito de Oliveira ${ }^{5}$, Elber Costa de Jesus ${ }^{6}$
}

\begin{abstract}
The Poço Verde region is the largest bean producer in the State of Sergipe and the twelfth in Brazil, being the second largest producer of irrigated corn in the State. Most of the cultivated area is without irrigation, which provides low productivity compared to regions that use irrigated agriculture, such as the municipality of Simão Dias that grows irrigated beans and corn, reaching almost twice as much productivity (IBGE, 2015). Irrigation is an alternative to increase productivity, but without proper management it results in wasted water and low productivity. The use of reference evapotranspiration (ETo) represents a very widespread management in the world. However, there are several methods for estimating it. In this context, the objective of this work was to estimate the ETo by the empirical methods of Camargo, Hargreaves-Samani, Blaney-Criddle and Linacre, and to compare them with the PenmanMonteith method, standard of the United Nations, for the climate conditions of the city of Poço Verde at the Sergipe State, using climatological data from the automatic meteorological station of the National Meteorological Institute (INMET). The correlation between the Camargo, Hargreaves-Samani, Blaney-Criddle, Linacre and standard Penman-Monteith methods was performed based on statistical indicators, in order to observe the precision given by the correlation coefficient (r) that is associated to the deviation between estimated and measured values indicating the degree of dispersion of the data obtained in relation to the mean. The Hargreaves-Samani method had a good correlation in the estimation of ETo with the PenmanMonteith method.
\end{abstract}

Key-words: Penman-Monteith, Hargreaves-Samani, irrigation.

\footnotetext{
${ }^{1}$ Professor do Departamento de Engenharia Agrícola, UFS, São Cristovão, Sergipe, rrgomesfilho@hotmail.com; ${ }^{2}$ Engenheiro Agrícola, mestrando em Recursos Hídricos, UFS, São Cristovão, Sergipe, igorsantos1993@gmail.com;

${ }^{3}$ Graduando em Engenharia Agrícola, UFS, São Cristovão, Sergipe, leno_120@hotmail.com; ${ }^{4}$ Graduanda em Engenharia Agrícola, UFS, São Cristovão, Sergipe, ketylenvs@hotmail.com; ${ }^{5}$ Graduanda em Engenharia Agrícola, UFS, São Cristovão, Sergipe, deby.thata@hotmail.com; ${ }^{6}$ Graduando em Engenharia Agrícola, UFS, São Cristovão, Sergipe, elber_costa1709@hotmail.com;
} 


\title{
ESTIMATIVA DA EVAPOTRANSPIRAÇÃO DE REFERÊNCIA PARA A REGIÃO DE POÇO VERDE
}

\begin{abstract}
RESUMO
A região de Poço Verde é a maior produtora de feijão do Estado de Sergipe e a décima segunda do Brasil, sendo a segunda maior produtora de milho irrigado no Estado. A maior parte da área cultivada é sem irrigação, o que proporciona baixa produtividade comparada com regiões que utilizam a agricultura irrigada, como por exemplo, o município de Simão Dias que cultiva feijão e milho irrigados, atingindo produtividade de quase duas vezes mais (IBGE, 2015). A irrigação é uma alternativa para aumentar a produtividade, porém sem o manejo adequado resulta num desperdício de água e baixas produtividades. A utilização da evapotranspiração de referência (ETo) representa um manejo bastante difundido no mundo. Entretanto, existem diversos métodos para estimá-lo. Dentro deste contexto, o objetivo deste trabalho foi estimar a ETo pelos métodos empíricos de Camargo, Hargreaves-Samani, Blaney-Criddle e Linacre, e compará-los com o método de Penman-Monteith, padrão da Organização das Nações Unidas (ONU), para as condições climáticas do município de Poço Verde, utilizando dados climatológicos da estação meteorológica automática do Instituto Nacional de Meteorologia (INMET). A correlação entre os métodos de Camargo, Hargreaves-Samani, Blaney-Criddle, Linacre e o método padrão de Penman-Monteith foi realizada com base em indicadores estatísticos, a fim de se observar a precisão dada pelo coeficiente de correlação (r) que está associado ao desvio entre valores estimados e medidos indicando o grau de dispersão dos dados obtidos em relação à média. O método de Hargreaves-Samani teve boa correlação na estimativa da ETo com o método de Penman-Monteith.
\end{abstract}

Palavras-chave: Penman-Monteith, Hargreaves-Samani, irrigação.

\section{INTRODUCTION}

Irrigation is an alternative to reduce the risk of crop and corn crop losses due to the scarcity of rainfall in the Poço Verde region. In the year 2016 the cumulative precipitation was $561 \mathrm{~mm}$, and for the first four months of the year had already rained $198 \mathrm{~mm}$, while in 2017, in the first four months, the accumulated was $140 \mathrm{~mm}$. For irrigation use in semi-arid regions where water resources are limited, it is essential to estimate the water requirements of crops with greater precision (SILVA et al., 2015).

The basis for the correct application of irrigation in a given crop is through the Evapotranspiration of the crop (ETc), which uses the local Evapotranspiration (ETo) data and a crop coefficient $(\mathrm{Kc})$ (BERNARDO et al., 2006 ).

The ETo can be calculated through direct and indirect methods (BERNARDO et al., 2006). Indirect methods are calculated using pre-established equations such as Camargo,
Linacre, Hargreaves-Samani, Blaney Criddle, among others. The standard method is PenmanMonteith.

The choice of which method to use depends on the data available at the study site (ARAÚJO et al., 2007). The values obtained from ETo can vary depending on the method used, the size of the historical series and even according to the accuracy of the data obtained, which may influence the determination of the irrigation level and the management of the system (ARAÚJO et al., 2007).

Silva et al. (2016) verified that it is not recommended to estimate the ETo by the Penman-Monteith standard method for Aracaju city when only maximum and minimum air temperature data are available.

Based on the above, this work had the objective of estimating the reference evapotranspiration for the city of Poço Verde by Camargo, Linacre, Hargreaves-Samani, Blaney Criddle and Penman-Monteith methods, correlating with the latter. 


\section{MATERIAL AND METHODS}

The daily data of temperature, humidity, pressure, wind speed and solar radiation were obtained in an automatic meteorological station of the National Meteorological Institute INMET located in the city of Poço Verde at the Sergipe State.

The EToCalc software was used to estimate ETo by Camargo, Linacre, HargreavesSamani, Blaney Criddle and Penman-Monteith methods. The climatological data from May 2014 to July 2016 were tabulated and estimated the Reference Evapotranspiration (ETo) values by the following empirical methods.

The Camargo method (1971) was a simplification of the Thorntwaite method (1948). It has the advantage of only using the average air temperature and, as a disadvantage, does not consider the evaporating power of the air that the original Thorntwaite method is based on. The additional advantage of this method is that there is no need to use normal air temperature data. The ETo is estimated directly by the following equation:

$$
\mathrm{ET}_{\mathrm{o}}=0,01 \mathrm{Q}_{\mathrm{o}} \mathrm{T}_{\text {med }}
$$

where: Qo is the extraterrestrial solar radiation (tabulated as a function of local latitude and the month), expressed in $\mathrm{mm}$ of equivalent evaporation, $\mathrm{T}_{\text {med }}$ is the average temperature of the period considered in ${ }^{\circ} \mathrm{C}$.

The Hargreaves-Samani method was developed for California's semi-arid climatic conditions in 1985. It is recommended by FAO (ALLEN at al., 1998) as an option for estimating ETo, when there is only availability of air temperature data. It is not universally applicable, therefore it must be calibrated for other climatic conditions. Normally, it causes overestimate in humid climate conditions (ALLEN et al., 1998). Hargreaves and Samani applying regression analysis on daily Davis-California reference evapotranspiration data obtained the following equation:

$$
\mathrm{ET}_{\mathrm{o}}=0,0023\left(\mathrm{~T}_{\text {med }}+17,8\right)\left(\mathrm{T}_{\max }-\mathrm{T}_{\min }\right)^{0,5} \mathrm{R}_{\mathrm{a}}(2)
$$

where: $\mathrm{T}_{\text {med, }} \mathrm{T}_{\max }$ and $\mathrm{T}_{\min }$ in ${ }^{\circ} \mathrm{C}$ represent respectively mean, maximum and minimum temperatures and $\mathrm{R}_{\mathrm{a}}$ is the solar radiation at the top of the atmosphere ( $\mathrm{mm}_{\text {day }}$ ${ }^{1}$ ), obtained by equation or tables.

The Blaney Criddle method was developed for a semi-arid region of New Mexico and Texas located in the western United States of America in 1950. Doorenbos \& Pruitt (1984) proposed the application of a correction factor, using humidity, wind speed and application of the method in various climatic conditions (MELO \& FERNANDES, 2012). The ETo is estimated directly by the following equation:

$$
\mathrm{ET}_{\mathrm{o}}=\mathrm{c}[(0,457 \mathrm{~T}+8,13) \mathrm{P}]
$$

where: $\mathrm{c}$ is the regional adjustment coefficient of the equation (tabulated as a function of solar brightness, wind speed and minimum relative humidity); $\mathrm{T}$ is the monthly mean temperature in ${ }^{\circ} \mathrm{C}$ and $\mathrm{P}$ is the monthly percentage of annual hours of sunlight.

The Linacre method was originally tested for Australian climatic conditions, is a method based on the simplification of the Penman-Monteith method using temperature data (maximum, minimum and dew point) as a function of latitude and altitude (MELO \& FERNANDES , 2012). The estimation equation of ETo by the method of Linacre (1977) is:

$$
\mathrm{ET}_{\mathrm{o}}=\frac{700 \frac{\left(\mathrm{T}_{\mathrm{med}^{+}}+0,006 \mathrm{z}\right)}{(100-\varnothing)}+15\left(\mathrm{~T}_{\mathrm{med}^{-}} \mathrm{T}_{\mathrm{d}}\right)}{\left(80-\mathrm{T}_{\mathrm{med}}\right)}
$$

The Penman-Monteith method considers that the reference evapotranspiration incorporates the aerodynamic and thermodynamic aspects, includes in its deduction the resistance to the sensible heat flow and water vapor (FERNANDES et al., 2011). It is recommended by FAO as the standard method (ALLEN et al., 1998) for estimation of ETo, described by the equation:

$$
\mathrm{ET}_{\mathrm{o}}=\frac{0,408 \Delta\left(\mathrm{R}_{\mathrm{n}}-\mathrm{G}\right)+\gamma \frac{900}{\mathrm{~T}+273} \mathrm{U}_{2}\left(\mathrm{e}_{\mathrm{s}}-\mathrm{e}_{\mathrm{a}}\right)}{\Delta+\gamma\left(1+0,34 \mathrm{U}_{2}\right)}
$$

where: $\Delta$ is the slope of the saturation vapor pressure curve, in $k P a{ }^{\circ} C^{-1}$; $\mathrm{Rn}$ is the 
surface radiation balance, in $M J \mathrm{~m}^{-2}$ day $^{-1}$; $\mathrm{G}$ is the heat flux in the soil, in $M J m^{-2} d_{a y}^{-1}$; $\gamma$ is the psychrometric constant, in $\mathrm{kPa}^{\circ} \mathrm{C}^{-1}$; $\mathrm{T}$ is the air temperature at $2 \mathrm{~m}$ in height, at ${ }^{\circ} \mathrm{C}$; $\mathrm{U}_{2}$ is the wind speed at the height of $2 \mathrm{~m}$, in $\mathrm{m} \mathrm{s}^{-1}$; is the vapor saturation pressure, in $\mathrm{kPa}$; e is the current vapor pressure of the air, in $k P a$.

In order to compare and analyze the results, was used criteria involving the standard error of estimation (SEE), standard error of the adjusted estimate (SEEa), coefficients of adjustment of the linear equations with their respective determination coefficients $\left(\mathrm{R}^{2}\right)$, (JENSEN et al., 1990).

$$
\begin{aligned}
& \mathrm{SEE}=\left(\frac{\sum\left(\mathrm{Y}_{\mathrm{i}}-\mathrm{Y}_{\mathrm{m}}\right)^{2}}{\mathrm{n}-1}\right)^{0,5} \\
& \mathrm{SEE}_{\mathrm{a}}=\left(\frac{\sum\left(\mathrm{Y}_{\mathrm{ic}}-\mathrm{Y}_{\mathrm{m}}\right)^{2}}{\mathrm{n}-1}\right)^{0,5}
\end{aligned}
$$

Where: $\mathrm{Y}_{\mathrm{i}}$ is the evapotranspiration estimated by the methods of Linacre, Hargreaves-Samani, Blaney-Criddle and Camargo $\left(\mathrm{mm}\right.$ day $\left.^{-1}\right), \quad \mathrm{Y}_{\mathrm{m}}$ is the evapotranspiration estimated by the PenmanMonteith method $\left(\mathrm{mm} d a y^{-1}\right), \mathrm{n}$ is the total number of observations and $\mathrm{Y}_{\text {ic }}$ is the ETo estimate by the Penman-Monteith method, corrected by linear regression coefficients $(\mathrm{mm}$ day $\left.^{-1}\right)$.

The correlations between the methods of estimation of reference evapotranspiration were performed statistically through the linear equation:

$$
\mathrm{y}=\mathrm{ax}+\mathrm{b}
$$

where: $\mathrm{y}$ represents a dependent variable; $x$ the independent variable; $a$ and $b$ are angular and linear coefficients of the linear regression equation. The variable depends $\mathrm{y}$ corresponds to the values estimated by the Camargo, Hargreaves-Samani, Blaney-Criddle and Linacre methods, while the independent variable $\mathrm{x}$ corresponds to the values obtained by the Penman-Monteith standard method.

The correlation between the Camargo, Hargreaves-Samani, Blaney-Criddle, Linacre and standard Penman-Monteith methods was performed based on statistical indicators, in order to observe the precision given by the correlation coefficient ( $\mathrm{r}$ ) that is associated with the deviation between estimated and measured values indicating the degree of dispersion of the data obtained in relation to the mean. The correlation coefficient can be calculated from the following equation:

$$
\mathrm{r}=\sqrt{\frac{\sum\left(\mathrm{Y}_{\mathrm{est}} \mathrm{Y}_{\mathrm{med}}\right)^{2}}{\sum\left(\mathrm{Y}-\mathrm{Y}_{\mathrm{med}}\right)^{2}}}
$$

where: $\mathrm{Y}_{\text {est }}$ represents the evapotranspiration estimated; $\mathrm{Y}$ represents the evapotranspiration observed and $Y_{\text {med }}$ represents the mean of the evapotranspirations observed.

The correlation coefficient values found were classified according to the Hopkins methodology (Table 1).

Table 1. Classification of correlations according to correlation coefficient (r).

\begin{tabular}{cc}
\hline $\begin{array}{c}\text { Correlation Coefficient } \\
(\mathrm{r})\end{array}$ & Classification \\
\hline $0.0-0.1$ & Very low \\
$0.1-0.3$ & Low \\
$0.3-0.5$ & Mean \\
$0.5-0.7$ & High \\
$0.7-0.9$ & Very High \\
$0.9-1.0$ & Almost perfect \\
\hline
\end{tabular}

The test developed by Willmott (1985) was also applied, which by means of a coefficient designated as agreement or accuracy (d), mathematically quantifies the data dispersion in relation to the standard method, being calculated by the equation: 


$$
\mathrm{d}=1-\left[\frac{\sum\left(\mathrm{P}_{\mathrm{i}}-\mathrm{O}_{\mathrm{i}}\right)^{2}}{\sum\left(\left|\mathrm{P}_{\mathrm{i}}-\mathrm{O}\right|+\mid \mathrm{O}_{\mathrm{i}}-\mathrm{O}\right)^{2}}\right]
$$

where: $\mathrm{P}_{\mathrm{i}}$ is the evapotranspiration estimated by the method tested $(\mathrm{mm})$; $\mathrm{O}_{\mathrm{i}}$ is the ETo estimated by the standard method ( $\mathrm{mm}$ ) and $\mathrm{O}$ is the mean of the values obtained by the standard method (mm).
With the correlation between
the data and the accuracy, the coefficient of performance (c) (Table 2) was calculated, which is determined by the product of the correlation coefficient and the correctness $(\mathrm{c}=\mathrm{rxd}$ ) (CAMARGO \& SENTELHAS, 1997).

Table 2. Values of the coefficient of performance according to Camargo \& Sentelhas (1997).

\begin{tabular}{cc}
\hline Value of "c" & Performance \\
\hline$>0.85$ & Great \\
$0.76-0.85$ & Very good \\
$0.66-0.75$ & Good \\
$0.61-0.65$ & Mean \\
$0.51-0.60$ & Suffering \\
$0.41-0.50$ & Bad \\
$\leq 0.40$ & Terrible \\
\hline
\end{tabular}

\section{RESULTS AND DISCUSSION}

In Figures 1, 2, 3 and 4 the relationships between the values calculated by the Camargo, Hargreaves-Samani, Blaney-Criddle and
Linacre methods, respectively, can be observed with the values obtained by the standard Penman-Monteith method for the municipality of Poço Verde from May 2014 to July 2016.

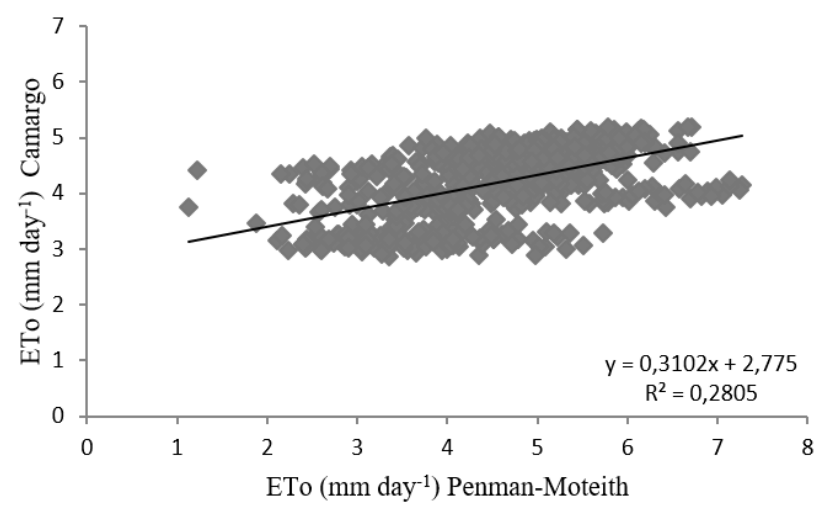

Figure 1. Relationship between the values calculated by the Camargo method with the values obtained by the Penman-Monteith method for the municipality of Poço Verde from May 2014 to July 2016.

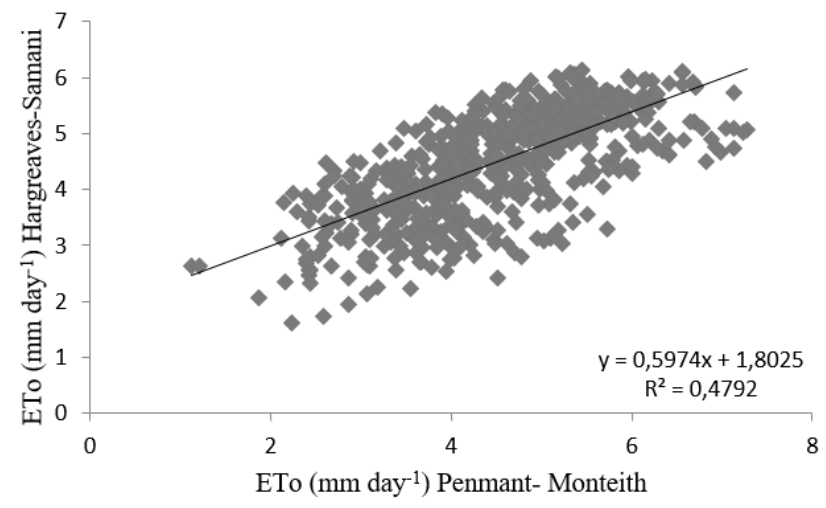


Figure 2. Relationship between the values calculated by the Hargreaves-Samani method with the values obtained by the Penman-Monteith method for the municipality of Poço Verde from May 2014 to July 2016.

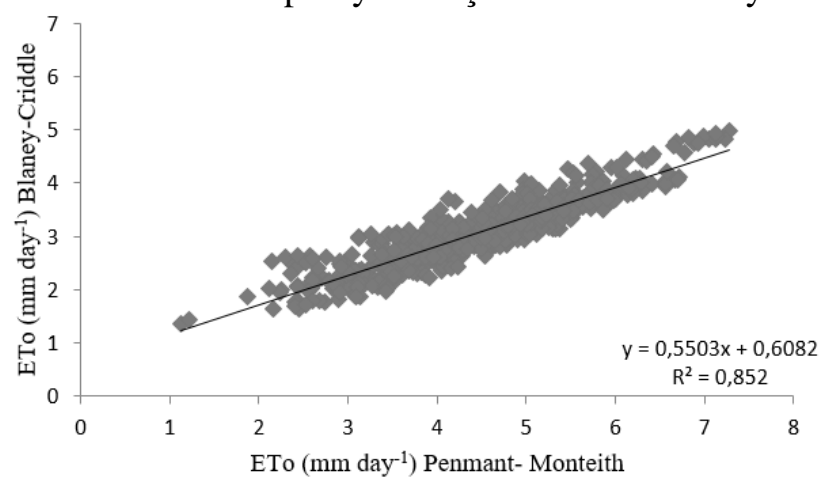

Figure 3. Relationship between the values calculated by the Blaney-Criddle method with the values obtained by the Penman-Monteith method for the municipality of Poço Verde from May 2014 to July 2016.

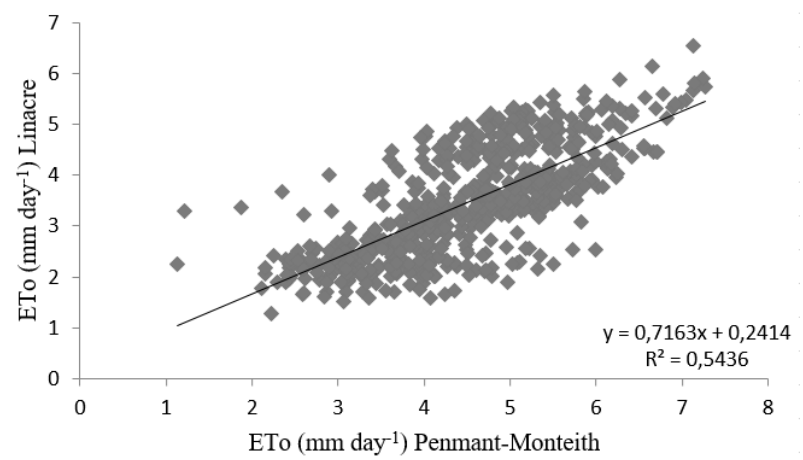

Figure 4. Relationship between the values calculated by the Linacre method with the values obtained by the Penman-Monteith method for the municipality of Poço Verde from May 2014 to July 2016.

The values of SEE, SEEa, d, $r$ and c, with the methods studied are listed in Table 3.

Table 3. Relationship of the coefficients analyzed for the Poço Verde region, using data from the INMET Automatic Meteorological Station

\begin{tabular}{cccccc}
\hline ETo Estimation Methods & SEE & SEEa & d & r & c \\
\hline Camargo & 0.99 & 0.83 & 0.65 & 0.53 & 0.35 \\
Hargreaves \& Samani & 0.81 & 0.44 & 0.88 & 0.69 & 0.61 \\
Blaney-Criddle & 1.53 & 1.51 & 0.63 & 0.92 & 0.58 \\
Linacre & 1.30 & 1.09 & 0.71 & 0.74 & 0.52 \\
\hline
\end{tabular}

It can be observed that the values of SEE, based on daily values of ETo, that presented a variation of 0.81 to $1.53 \mathrm{~mm} \mathrm{day}^{-1}$, with the lowest values for the Hargreaves-Samani method and the higher values for the BlaneyCriddle method (Table 3).

The average variation of the ETo values estimated by the different methods and corrected by the linear regression coefficients was 0.44 to $1.51 \mathrm{~mm} \mathrm{day}^{-1}$, with the lowest values obtained by the Hargreaves \& Samani method and the highest values by the method of Blaney-Criddle. The SEEa values for all methods were reduced, which indicates that linear regression improved the fit.

The Hargreaves-Samani method presented the best performance, according to the classification proposed by Camargo \& Sentelhas (Table 2). The methods of Blaney-Criddle and Linacre presented a performance classified as suffering. The Linacre method presented poor performance.

According to Table 3 and Figures 1, 2, 3 and 4 , there was an almost perfect correlation in the ETo values obtained by the Blaney-Criddle methods $(r=0.92)$, a correlation classified as 
very high for the Linacre method $(r=0.74)$ and a correlation classified as high for the Camargo $(r=0.53)$ and Hargreaves-Samani $(r=0.69)$ methods with those obtained by the PenmanMonteith method, according to the classification in Table 1.

Silva et al. (2010) observed that the Hargreaves-Samani method for estimating ETo for the municipality of Tauá and Sobral in the state of Ceará showed a very high correlation ( $\mathrm{r}$ $=0.89$ ) in relation to the Penman-Monteith method, which is higher to the one found for Poço Verde at the Sergipe State.

For the irrigated perimeters California, Jabiberi, Jacarecica and Piauí in the State of Sergipe, Sousa et al. (2010) estimated the ETo based on the "Class" A, Solar Radiation, Hargreaves-Samani and Linacre methods, comparing them with the Penman-Monteith method, verified that the best performances were obtained with the methods that used the solar radiation as an input element, among them, the one of Hargreaves-Samani, obtaining a very good performance and correlation coefficient classified as very high, agreeing with the results obtained for the municipality of Poço Verde at the Sergipe State.

Gonçalves et al. (2009) comparing methods of estimation of ETo with the standard Penman-Monteith method for the municipality of Sobral at the Ceará State, also obtained a correlation classified as very high $(r=0.81)$ of the Hargreaves-Samani method with the Penman-Monteith method, similar to the result obtained for Poço Verde at the Sergipe State.

Barros et al. (2009) evaluated the estimation of reference evapotranspiration (ETo) for the region of Seropédica at the Rio de Janeiro State, using Penman-Monteith-FAO 56, Hargreaves-Samani, Camargo, Priestley-Taylor, Makking and Class A Tank, verified that the best ETo estimates were obtained using the Hargreaves-Samani method.

Batista et al. (2007) compared the methods of Penman 63, FAO-Penman corrected, FAO radiation, Blaney-Criddle and HargreavesSamani with the Penman-Monteith standard method for the region of Canindé of São Francisco at the Sergipe State. They found that the Blaney-Criddle and FAO radiation methods presented better adjustments with the PenmanMonteith method, but the Hargreaves-Samani method showed a very high correlation $(\mathrm{r}=$ 0.87), results similar to those obtained for Poço Verde at the Sergipe State.

Borges and Mendiondo (2007) measured the accuracy of six empirical equations (BlaneyCriddle, Hargreaves-Samani, Camargo, Thornthwaite, Hamon and Kharrufa) compared to the Penman-Monteith equation and found that the Hargreaves-Samani equation with regional coefficients presented confidence indexes above 0.995 for the Jacupiranga river basin and is recommended due to its feasibility and simplicity.

Oliveira et al. (2001) evaluated different models of estimation of reference evapotranspiration and compared the PenmanMonteith model to some locations in the State of Goiás and Federal District, concluding that all models presented high significance with Penman-Monteith, and the model that most approached the standard was FAO-Penman, followed by the Hargreaves-Samani and FAORadiation models, corroborating with the result obtained by the Hargreaves-Samani method for Poço Verde at the Sergipe State.

It was observed that the HargreavesSamani method for the semi-arid region presented good results when compared to the Penman-Monteith method, but in humid and sub-humid regions, the results with the Hargreaves-Samani method are not satisfactory, as was observed by Tagliaferre et al. (2010), which evaluated the performance of the Penman-modified, Solar Radiation, BlaneyCriddle, Hargreaves-Samani, Priestley-Taylor and Turc empirical methods in relation to the standard Penman-Monteith-FAO method for Southern Bahia climatic conditions, in the Municipality of Eunápolis, whose climate is classified as sub-humid. The Blaney-Criddle and Solar Radiation methods presented better performance for estimation of ETo in four time scales: daily, three, five and seven days. The Hargreaves-Samani method stood out as the worst method used to estimate ETo.

\section{CONCLUSIONS}


In the climatic conditions of the study site, for the evaluated methods, the HargreavesSamani method presented a correlation coefficient classified as high and a good performance, having a good fit with the Penman-Monteith standard method and showing good reliability in the estimation of evapotranspiration to the Poço Verde at the Sergipe State.

\section{ACKNOWLEDGEMENTS}

To the CNPq / PIBIC program of the Federal University of Sergipe for the granting of the Scientific Initiation Grant.

\section{REFERENCES}

ALLEN, R. G.; PEREIRA, L. S.; RAES, D.; SMITH, M. Crop evapotranspiration: guidelines for computing crop water requirements. FAO: Rome, 1998. 300p. (Irrigation and Drainage Paper, 56).

ARAÚJO, F. W; COSTA, A. A. S; SANTOS, A. E. dos. Comparação entre métodos de estimativa da evapotranspiração de referência para Boa Vista-RR. Caatinga (Mossoró, Brasil), v.20, n.4, p.84-88, 2007.

BARROS, V. R.; SOUZA, A. P.; CARVALHO, D. F.; SILVA, L. B. D. Avaliação da evapotranspiração de referência na Região de Seropédica, Rio de Janeiro, utilizando lisímetro de pesagem e modelos matemáticos. Revista Brasileira de Ciências Agrárias, v. 4, n. 2, p.198-203, 2009.

BATISTA, W. R. M.; FACCIOLI, G. G.; SILVA, A. A. G. Determinação e comparação entre métodos de estimativas de evapotranspiração de referência para região de Canindé do São Francisco-SE. Revista da FAPESE. v.3, n.2, p.71-76, 2007.

BERNARDO, S; SOARES, A.A; MANTOVANI, E.C. Manual de irrigação. 8. ed. Viçosa: UFV, 2006. 611 p.
BORGES, A. C.; MENDIONDO, E. M. Comparação entre equações empíricas para estimativa da evapotranspiração de referência na Bacia do Rio Jacupiranga. Revista Brasileira de Engenharia Agrícola e Ambiental. v.11, n.3, p.293-300, 2007.

CAMARGO, A. P. Balanço hídrico no Estado de São Paulo. 3.ed. Campinas: IAC, 1971. 24p. (Boletim Técnico, 116).

CAMARGO, A. P.; SENTELHAS, P. C. Avaliação do desempenho de diferentes métodos de estimativa da evapotranspiração potencial no Estado de São Paulo. Revista Brasileira de Agrometeorologia, v.5, p.89-97, 1997.

DOORENBOS, J.; PRUITT, W. Guidelines for predicting crop water requirements. FAO: Rome, 1984. 178p. (Irrigation and Drainage Paper, 24).

FERNANDES, A. L. T.; FRAGA JÚNIOR, E. F.; TAKAY, B. Y. Avaliação do método Penman-Piche para a estimativa da evapotranspiração de referência em Uberaba MG. Revista Brasileira de Engenharia Agrícola e Ambiental, Campina Grande, v.15, n.3, p.270-276, 2011.

GONÇALVES, F. M.; FEITOSA, H. de O.; CARVALHO, C. M. de; GOMES FILHO, R. R.; VALNIR JUNIOR, M. Comparação de métodos da estimativa da evapotranspiração de referência para o município de Sobral-CE. Revista Brasileira de Agricultura Irrigada, v.3, n.2, p.71-77. 2009.

IBGE. Produção Agrícola Municipal. 2014. Disponível em: $<\underline{\text { http://www.cidades.ibge.gov.br/> }}$. Acesso em 21 de abril de 2017.

IBGE. Produção Agrícola Municipal. 2015. Disponível em: $<$ http://www.cidades.ibge.gov.br/s. Acesso em 21 de abril de 2017. 
JENSEN, M. E.; BURMAN, R. D.; ALLEN, R. G. 1990. Evapotranspiration and Irrigation Water Requirements. ASCE Manuals and Reports on Engineering Practice No. 70, Am. Soc. Civil Engr., New York, NY. 332 pp.

LINACRE, E. T. A simple formula for estimating evapotranspiration rates in various climates, using temperature data alone. Agricultural Meteorology, Amsterdam, v.18, n.1, p.409-424, 1977.

MELO, G. L. de; FERNANDES, A. L. T. Evaluation of empirical methods to estimate reference evapotranspiration in Uberaba, State of Minas Gerais, Brazil. Engenharia Agrícola, Jaboticabal, v.32, n.5, p.875-888. 2012.

OLIVEIRA, L. F. C.; CARVALHO, D. F.; ROMÃO, P. de A.; CORTÊS, F. C. Estudo comparativo de modelos de estimativa da Evapotranspiração de referência para algumas localidades No estado de Goiás e Distrito Federal. Pesquisa Agropecuária Tropical, 31(2): 121-126, 2001.

SILVA, M. G.; BATISTA, L. S.; GOMES FILHO, R. R.; CARVALHO, C. M. Estimativa da evapotranspiração de referência por penmanmonteith fao 56 usando dados meteorológicos limitados em Aracaju, Sergipe. Revista Brasileira de Agricultura Irrigada, v.10, n.4, p.830-840. 2016.

SILVA, M. G.; OLIVEIRA, I. S.; CARMO, F. F.; LEDO, E. R. F.; SILVA FILHO, J. A. Estimativa da evapotranspiração de referência pela equação de Hargreaves-Samani no Estado do Ceará, Brasil. Revista Brasileira de Engenharia de Biossistemas, Tupã, v.9, n.2, p.132-141, 2015.

SILVA, M. G.; OLIVEIRA, J. B. ; LEDO, E. R. F. ; ARAÚJO, E. M. ; ARAÚJO, E. M. Estimativa da ETo pelos métodos de PenmanMonteith FAO 56 e Hargreaves-Samani a partir de dados de Tx e Tn para Sobral e Tauá no Ceará. Acta Tecnológica, v. 5, p. 52-68, 2010.

SOUSA, I. F.; SILVA, V. de P. R. da; SABINO, F. G.; NETTO, A. de O. A.; SILVA, B. K. N.; AZEVEDO, P. V. de. Evapotranspiração de referência nos perímetros irrigados do Estado de Sergipe. Revista Brasileira de Engenharia Agrícola e Ambiental. v.14, n.6, p.633-644, 2010

WILLMOTT, C. J. On the validation of models. Physical Geography, v.2, p.184-194, 198 